技術論文

\title{
超音波による壁面の法線方向の高速測定
}

\author{
大矢晃 久 ${ }^{* 1}$ 永島良昭 ${ }^{* 2}$ 油田信 一*1
}

\section{High Speed Measurement of Normal Direction of Walls by Ultrasonic Sensor}

\author{
Akihisa Ohya*1, Yoshiaki Nagashima*2 and Shin'ichi Yuta*1
}

\begin{abstract}
A novel ultrasonic sensing method which can measure the normal direction of walls is proposed. The inclination of the wall is calculated from the difference of the round-trip time-of-flight detected by using plural receivers. This sensor system has four receivers for the error correction using inconsistency check of the propagation times.
\end{abstract}

Key Words: Ultrasonic Sensor, Normal Direction of Wall, Mobile Robot, High Speed Measurement

\section{1. はじめに}

移動ロボット用の環境認識センサとしては，システム構成が 容易で安価な超音波センサがよく用いられる。通常の屋内環境 は, 多くの平らな壁面から構成されており,この場合, 壁面ま での距離だけでなく, その法線の方向も検出することが重要と なる。

超音波を使って壁面の法線方向を検出する方法としては，指 向性の鋭い超音波パルスをあらゆる方向に順次送受信し，反射 波の受信された方向を壁面の法線方向とみなす方法が考えられ る。また, 指向性のある程度広い超音波を送受して壁までの距 離を測定するという操作を, ロボットが移動しながら複数の位 置で繰り返し, ロボット自身の移動軌跡デー夕に基づいて壁面 の法線方向を求める方法もある [1][2]. ただし，このいずれの 方法においても, 壁面の法線方向を測定するためには超音波の 送受を何回か繰り返す必要があり，これを高速に測定すること は難しかった。

これに対して, 受信器の数を複数にすることにより, 壁面の 位置とその法線方向を 1 度の計測で得ることができる方法も提 案されている $[3]$ 。筆者らはこれまでに, この方法に基づく移 動ロボット用超音波センサシステムを構築し，実験によってそ の有効性を検証してきた [4].しかしながら，このシステムに おいても受信波のリーディングエッジの誤検出に基づく大きな 角度計測誤差を軽減するためには, 複数回の計測を行い, 得ら れるデー夕を統計的に処理する必要があった。そこで, 受信器 の数を二つから四つに増やし, リーディングエッジの誤検出が

\footnotetext{
原稿受付 1994 年 7 月 4 日

*1 筑波大学

$* 2$ (株) 日立製作所

${ }^{* 1}$ University of Tsukuba

${ }^{* 2}$ Hitachi, Ltd.
}

あった場合でも 1 回の測定で壁面の位置とその法線方向を正し く計測できるよう，筆者らの提案した超音波センサシステムに 改良を加えた。本論文では, 本手法の原理, システムの構成, および実験による有効性の検証結果について述べる。

\section{2. 壁面の法線方向の測定原理}

一つの送信器と二つの受信器を用いた, 壁面の法線方向の測 定原理を Fig. 1 に示す。送信器（T）から超音波パルスを発射 し, 壁面で反射した超音波の伝搬時間を二つの受信器 (R) に より測定する。このとき，壁面の法線方向，すなわち反射波の 入射方向 $\theta$ は, 角度 $\theta$ が小さい範囲であれば, 二つの受信器 に受かるエコーの伝搬距離差 $\Delta l$ から次式のような近似関係に より求めることができる.

$$
\theta \approx \frac{\Delta l}{2 d}
$$

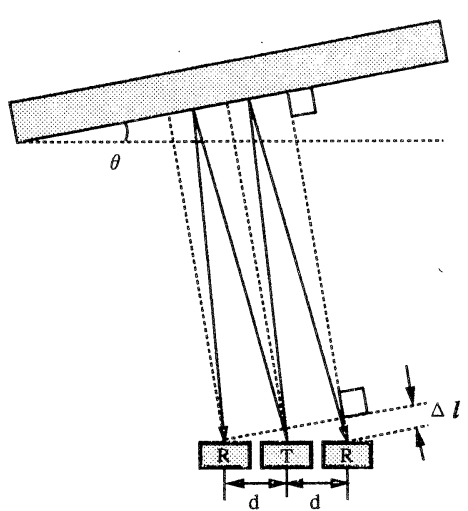

Fig. 1 Principle of the method for the measurement of the normal direction of the wall using one transmitter $(\mathrm{T})$ and two receivers $(\mathrm{R})$. 


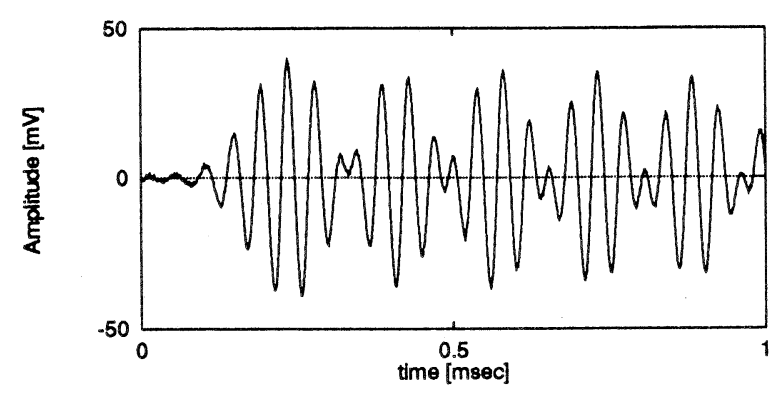

Fig. 2 An example of received echo signal.

ここで, 超音波の伝搬時間は，リーディングエッジの検出に 基づいて求められる。Fig. 2 は, 実際に受信される反射波形の 例であるが, 通常のシステムでは, このような反射波のレベル がある閾值を越えた瞬間をもって，リーディングエッジが検出 されたものとみなされる。このとき, 反射波の振幅の微妙な大 小により, 閾值を越える受信波の周期が受信器ごとに異なる場 合, これに起因して角度の算出に大きな誤差が生じる，そこで 筆者らは, 本来二つで足りる受信器の数をさらに増やして圥長 性を持たせることにより, リーディングエッジの誤検出のチェッ クを行う方法を考案した。

\section{3. 几長な受信器による角度測定誤差の補正}

今, 3 個の受信器をある間隔で横 1 列に並べたとすると, それ らに受かる超音波の伝搬時間の差は受信器間の間隔に比例して 変化するはずである。これに対して，伝搬時間の測定誤差は超 音波の周期の倍数の值しか取らないため，もしこの条件に反する 場合，いずれかの受信器間に相対的な位相誤差があることが分か り, 誤差の修正を行って正確な角度を求められる可能性がある.

本手法では, 送信器を中央とし, その両側に等間隔で二つず つ, 計四つの受信器を配置することとした。この場合, 各受信 器における伝搬時間の誤差が多くとも周期の 3 倍以内であれば, その誤差の存在を検出することができる。ただし，実際には 2 周期以上の誤差はほとんど発生しないため [4], 次のようなア ルゴリズムにより，1 周期の誤差を補正することとした。

・四つの受信器 $R_{1}, R_{2}, R_{3}, R_{4}$ で測定される距離を, 扮のお の $L_{1}, L_{2}, L_{3}, L_{4}$ とする. $L_{1} \sim L_{4}$ の四つの值から二つを 取り出す組み合わせは計 6 通りある。

・各組み合わせに対して, 他の二つの距離を計算により求め る、計算值と実際の測定値が等しいか, あるいはちょうど 1 周期の誤差に収まっていれば，その角度を採用する。

Fig. 3 を用いて，角度測定誤差の具体的な補正方法を説明す る. 同図中, 縦軸は各受信器で測定された超音波の伝搬距離で あり, 黒丸が各測定值を示している.この図では， $R_{1}$ と $R_{3}$ に は誤差はないが， $R_{2}$ と $R_{4}$ には超音波の 1 周期の測定誤差が 発生している場合を表している。ここで，上に述べたように四 つの測定值から二つを取り出して他の二つの距離を計算により 求めたとすると, それぞれ図中 1 ～6で示した直線上に值が存 在することになる，各直線に対して，計算値と実際の測定值が 等しいか, あるいはちょうど 1 周期の誤差に収まっているもの を調べてみると, 直線 2 と 5 だけが候補として残る。伝搬距離

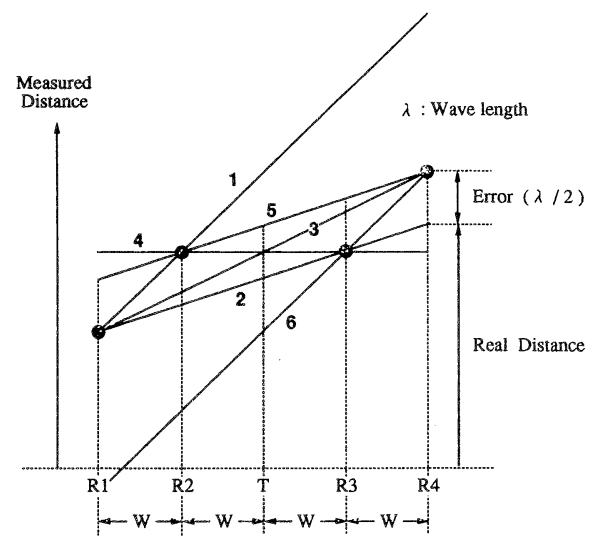

Fig. 3 An example of measured angle error elimination using four receivers.

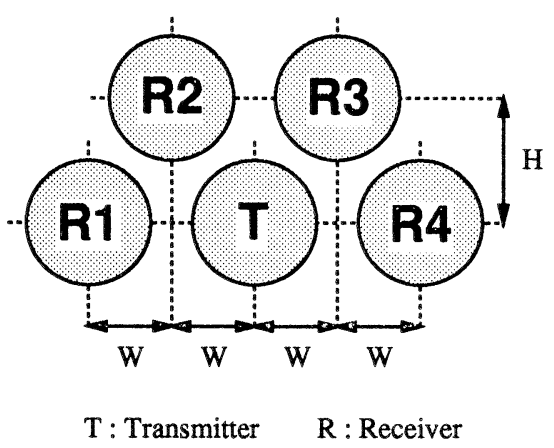

Fig. 4 Arrangement of the transducers.

の測定誤差は, 值の正方向にしか発生しないため, より近い直 線 2 を採用して角度を求めればよい。

この方法は, 受信器を 2 個だけ用いる場合と比べて測定角度 值そのものの精度を向上させるものではないが, リーディング エッジの誤検出に基づく離散的な角度測定誤差の発生確率を減 少させることができる. 三つ以上の受信器を用いる方法として は, 各受信器で得られる伝搬時間を単純に最小二乗法で直線に フィッティングして角度を求める方法も考えられる。しかし, そ のような方法ではリーディングエッジの誤検出がない場合には 測定精度が向上するが，リーディングエッジの誤検出が起こつ た場合に，その影響を取り除くことはできない。

\section{4. 測定システム}

トランスデューサ間の距離が長ければ, 角度測定において高 い精度を得ることができるが, 各受信器間での受信波の相関が 低くなるため, 前述した角度測定誤差が発生しやすくなる。 そ こで, 本システムではトランスデューサを横 1 列に並べるので はなく，上下に段差を設けた配置とした（Fig.4）。として，上 段の $R_{2}$ と $R_{3}$ が下段の $R_{1}$ と $R_{4}$ と同じ高さにあるとみなす ことができるように伝搬時間の補正を行うこととした。受信器 $R_{1} \sim R_{4}$ で測定された超音波の伝搬時間をおのおの $t_{1} \sim t_{4}$ と するとき, $t_{2}$ と $t_{3}$ に対する補正式は次式で与えられる。

$$
t_{2}=t_{2}-\frac{-t_{1}+t_{2}+t_{3}-t_{4}}{2}
$$




$$
t_{3}=t_{3}-\frac{-t_{1}+t_{2}+t_{3}-t_{4}}{2}
$$

トランスデューサ（村田製作所製，MA23L3）を Fig.4 に示 したように配置し，実験システムを製作した。ただし，図中W の值は $1.75[\mathrm{~cm}], \mathrm{H}$ の值は $3[\mathrm{~cm}]$ とした. 各トランスデュー

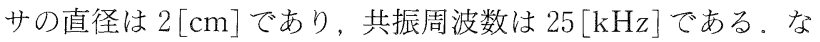
お, 各受信器における伝搬時間の測定は, 測定用の夕イマを 4 個用意することにより，同一の送信波に対して同時に行うこと ができるようにしてある。

\section{5. 壁面の法線方向測定実験}

まず，センサ全体を -54 度〜 54 度まで 0.9 度拈きに回転さ せ，平滑な壁面に対して角度を 1 回ずつ測定した。Fig.5 と Fig. 6 は，それぞれ壁面までの距離が $70[\mathrm{~cm}]$ と $150[\mathrm{~cm}]$ のと きの伝搬時間 (a) と求められた壁面の法線方向 (b) を示してい る。なお，図中の $\mathbf{R} 1 \sim \mathbf{R} 4$ は，Fig. 4 に示した配置図中のトラ ンスデューサの記号と一致させてある。Fig. 5，6の (a) より， 超音波の伝搬時間は角度の変化に比例して変化しているが, あ る角度において約 $40[\mu \mathrm{s}]$ の離散的な変化が現れている. $40[\mu \mathrm{s}]$ は $25[\mathrm{kHz}]$ の超音波の一周期に相当する時間であり,この変 化がリーディングエッジの誤検出によるものである、受信器を 2 個しか用いないシステムでは，ここで角度測定誤差が発生す るが，本手法では前述したアルゴリズムにより Fig. 5，60 (b) に示したように壁面の法線方向を正しく求めることができてい る。なお, 計測に要した時間は, 音波の往復伝搬時間, 補正計 算時間を含めて壁面までの距離が $70[\mathrm{~cm}]$ の場合には約 $5[\mathrm{~ms}]$, $150[\mathrm{~cm}]$ の場合には約 $10[\mathrm{~ms}]$ である。

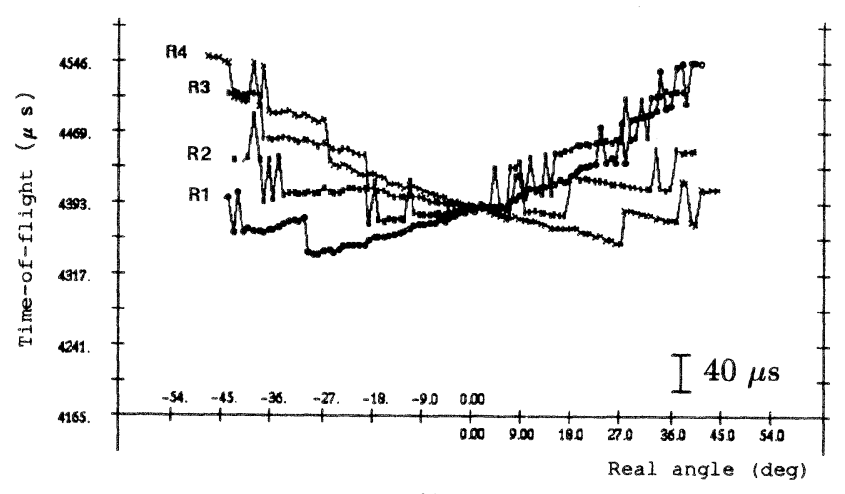

(a)

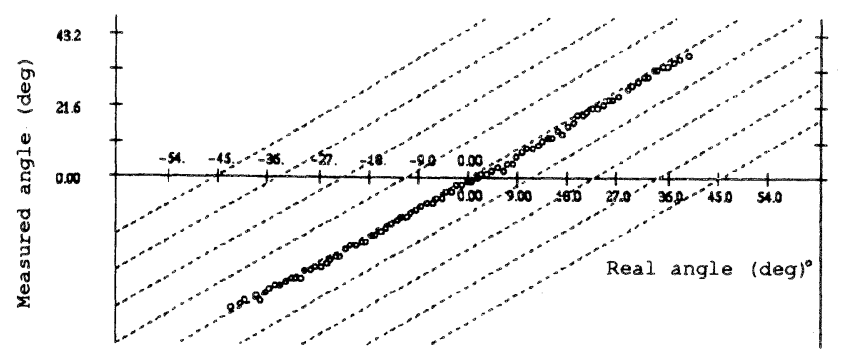

(b)

Fig.5 Measured time-of-fight (a) and the normal direction of the wall (b). (Distance to the wall: $70[\mathrm{~cm}]$ )
次に, 壁面までの距離を $50[\mathrm{~cm}] \sim 370[\mathrm{~cm}]$ まで $20[\mathrm{~cm}]$ お きに変化させ, 各距離においてセンサを -63 度〜 63 度まで 0.9 度扔きに回転させて, 角度を 1 回ずつ測定した。このとき, 角 度を正しく求めることのできた範囲を調べた結果を Fig.7 に示 す。この図は, 横軸がセンサと壁面との距離, 縦軸が壁面の角度 であり, 白い領域は壁面の法線方向が正しく求められた場合を 示しており，黒い領域は反射波が戻らなかったりして角度を求 めることができなかった場合を示している，この図から，距離 が $50[\mathrm{~cm}] \sim 150[\mathrm{~cm}]$ の間で壁面の角度が -27 度〜 27 度の範囲 内であれば，ほぼ確実に角度を得ることができると考えられる。

さらに, 壁面に対して $50[\mathrm{~cm}], 100[\mathrm{~cm}], 150[\mathrm{~cm}]$ の各距離 で，センサを -45 度〜 45 度まで 0.9 度扮きに回転させて角度 の測定をそれぞれ 50 回ずつ行い, 測定値の平均值と標準偏差 值を計算した結果を Fig. 8 に示す。縦軸は測定值の平均值と実 際の角度との差であり, 誤差棒はその長さを標準偏差值の 2 倍 としてある。この図からは, 角度測定の誤差は長距離になるほ ぞ発生しやすいが, その詿差は 2 度〜3 度程度であることが分 かる。また，角度が大きくなるにつれて誤差が増大するのは， 正弦関数の近似 $\theta \approx \sin \theta$ を用いた式（1）が成立しなくなって いることが原因と考えられる。なお，誤差が正に偏っているの は，センサと壁面を正対させて設置したときのアライメントの ずれによるものと思われる。

\section{6. ま と め}

本論文では，筆者らの提案している移動ロボット用の超音波 センサシステムに改良を加え, 壁面までの距離と壁面の法線方

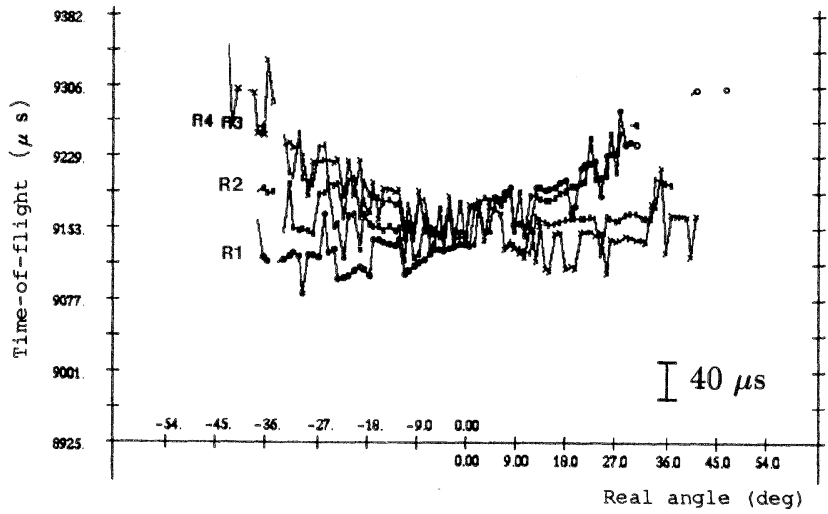

(a)

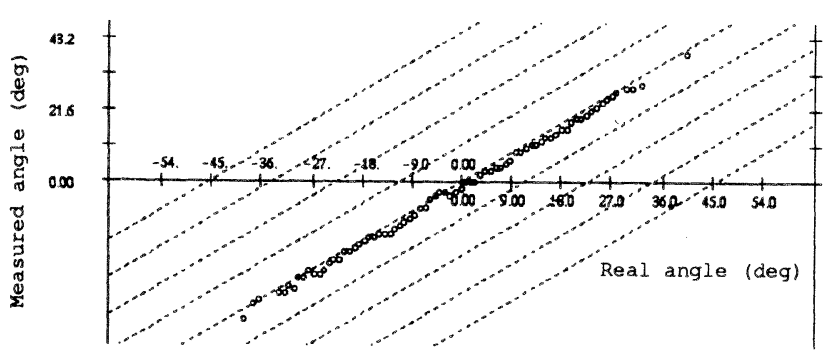

(b)

Fig.6 Measured time-of-flight (a) and the normal direction of the wall (b). (Distance to the wall: $150[\mathrm{~cm}]$ ) 


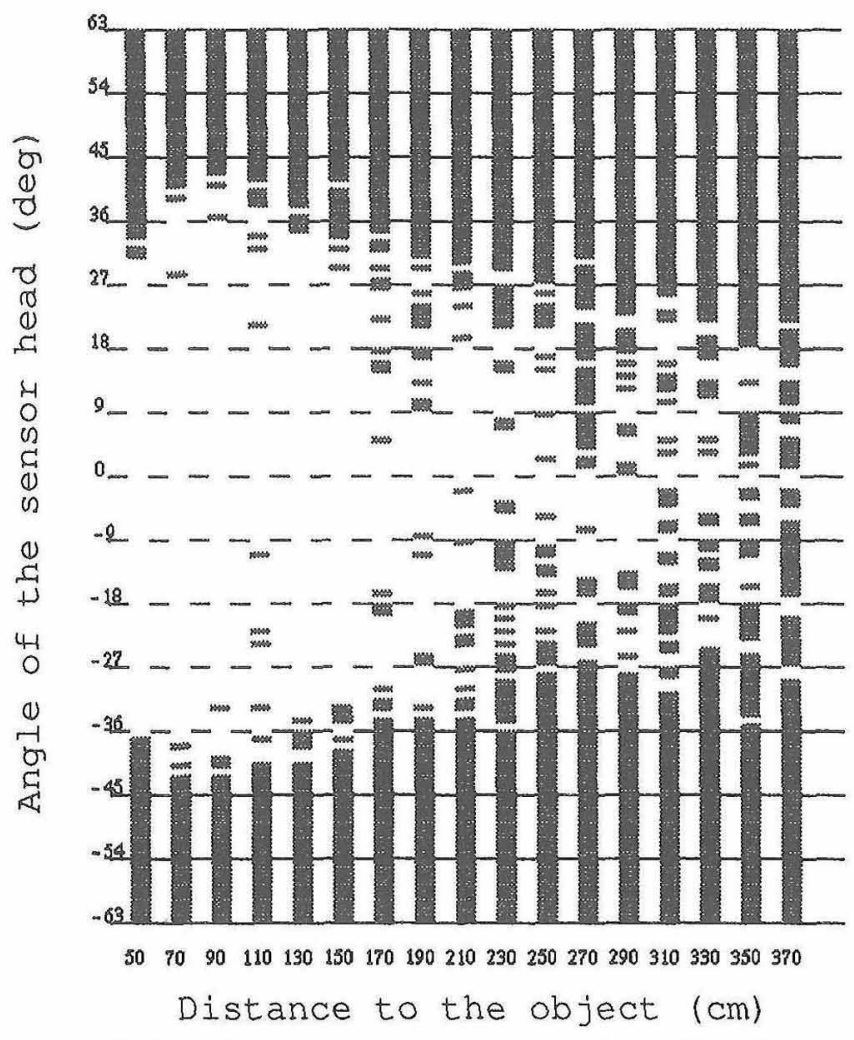

Fig. 7 Region where the normal direction of the wall can be measured.

向を高速に測定することのできる方法を提案した．本システム では, 一つの送信器と四つの受信器を用いることにより, 超音 波のリーディングエッジの誤検出に基づく角度測定䛊差を補正 している，本システムの有効性を検証するために測定システム を製作して実験を行った結果，本シスうムにより壁面の法線方 向が正しく求められることが分かった。

\section{参考文 献}

[1] H.P. Moravec and A. Elfes: "High Resolution Maps from Wide Angle Sonar," Proc. 1985 IEEE Int. Conf. on Robotics and Au-

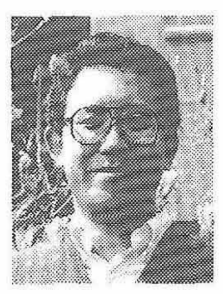

大矢晃久 (Akihisa Ohya)

1965 年 3 月 16 日生. 1987 年慶應義熟大学理工学部 電気工学科卒業. 1992 年同大学大学院理工学研究 科後期博士課程電気工学専攻修了. 工学博士. 同年 4 月筑波大学電子情報工学系助手. 1994 年同講師. 移動ロボットのためのセンシングシステムに関す る研究に従事。超音波センサ, 視覚センサとそれら を用いた移動ロボットのナビゲーションなどに興味を持つ，電子情報 通信学会, 計測自動制御学会, 日本音響学会各会員.

(日本ロボット学会正会員)

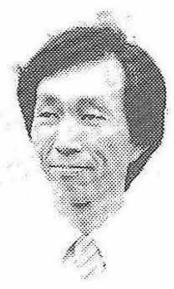

油田信一 (Shin'ichi Yuta)

1948 年 3 月 23 日生. 1975 年慶應義塾大学大学院 (電気工学専攻) 修了. 現在筑波大学電子情報工 学系教授、知能移動ロボット，ロボットセンサ，ロ ボット用コントローラなどの研究に従事。自動制 御や信号処理の理論と応用にも興味を持つ. 工学 博士.IEEE，計測自動制御学会などの会員.

(日本ロボット学会正会員)

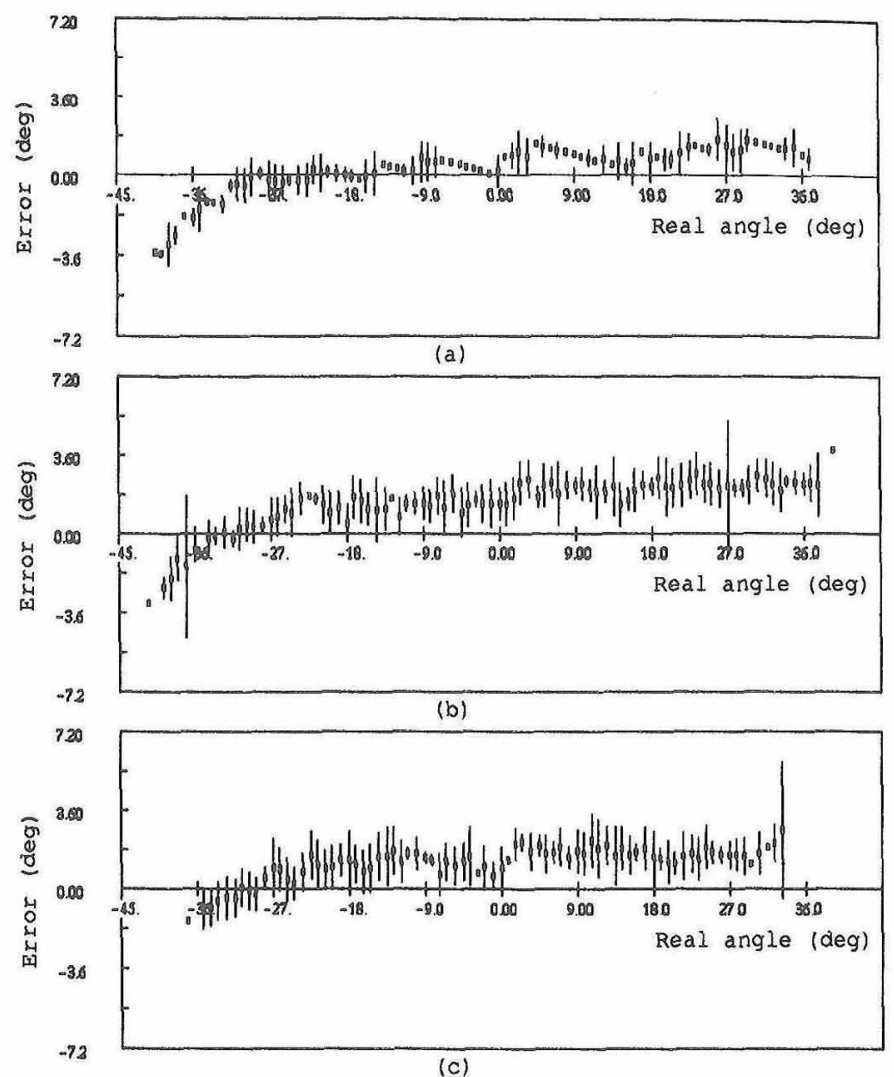

Fig. 8 The average and the standard deviation of the measured value of the normal direction of the wall. Distance to the wall is $50[\mathrm{~cm}]$ in (a), $100[\mathrm{~cm}]$ in (b) and $150[\mathrm{~cm}]$ in (c).

tomation, pp.116-121, 1985.

[2 ] J. Borenstein and Y. Koren: "Histogramic In-Motion Mapping for Mobile Robot Obstacle Avoidance," IEEE Trans. on Robotics and Automation, vol.7, no.4, pp.535-539, 1991.

[3] 中鴆新一, 高橋禎一: “分布型受信器を持つ姿勢計測用超音波センサ”, 日本ロボット学会誌, vol.6, no.1, pp.52-61, 1988.

[4] Y. Nagashima and S. Yuta: "Ultrasonic Sensing for A Mobile Robot to Recognize An Environment-Measuring The Normal Direction of Walls -," Proc. of the 1992 IEEE/RSJ Int. Conf. on Intelligent Robots and Systems, pp.805-812, 1992.

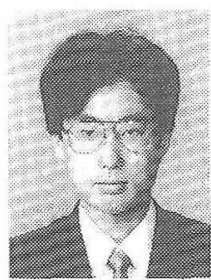

永島良昭 (Yoshiaki Nagashima)

1969 年 2 月 20 日生. 1991 年筑波大学第三学群情 報学類卒業。1 993 年同大学大学院修士課程理工学 研究科修了. 同年, 株式会社日立製作所に入社. 在 学中は, 移動ロボットの超音波センサの研究に従 事.

(日本ロボット学会正会員) 